\title{
Semi-automated assessment of the embryonic area of cucumber seeds and its relationship to germination and seedling length ${ }^{1}$
}

\author{
Francisco Guilhien Gomes-Junior ${ }^{2 *}$, Adrielle Aparecida Chiquito ${ }^{2}$, \\ Julio Marcos-Filho ${ }^{2}$
}

\begin{abstract}
Automated evaluations are highly useful for the seed industry to provide reliable information about different parameters of seed quality and fast results and to reduce errors based on human visual analysis. The objective of this research was to identify variations in the degree of embryo development in commercial cucumber seed lots and their relationship with physiological potential. Seeds of Supremo and Safira cultivars (four lots each), with germination above 90\%, were X-rayed, evaluated according to embryonic area (using the Tomato Analyzer software) and germinated $\left(4\right.$ days at $\left.25{ }^{\circ} \mathrm{C}\right)$; germination percentage and seedling length data were obtained. The average seed embryo area was 79.7 and $80.9 \%$ (Supremo and Safira, respectively), ranging from 4.4 and 1.0 percentage points among the lots of each cultivar. The semiautomated analysis using the Tomato Analyzer software identifies small variations in the embryonic development of cucumber seed lots; seeds with an embryonic area less than $78.1 \%$ were more likely to produce less developed seedlings.
\end{abstract}

Index terms: Cucumis sativus, quality control, imaging analysis, x-rays.

\section{Avaliação semiautomática da área embrionária de sementes de pepino e sua relação com a germinação e crescimento de plântulas}

\begin{abstract}
RESUMO - A automação das avaliações de diferentes atributos da qualidade de sementes é altamente desejável pela indústria de sementes, pois além da rápida obtenção de resultados, reduz erros humanos de interpretação decorrentes da análise baseada em estimativas visuais. Com o objetivo de identificar variações do grau de desenvolvimento embrionário em sementes de pepino de lotes comerciais, bem como sua possível relação com o potencial fisiológico, sementes das cultivares Supremo e Safira (quatro lotes cada), com germinação mínima de $90 \%$, foram radiografadas, submetidas à avaliação da área embrionária (software Tomato Analyzer) e avaliadas quanto à germinação $\left(4\right.$ dias a $\left.25^{\circ} \mathrm{C}\right)$ e comprimento de plântulas. A área embrionária média das sementes foi de 79,7 e 80,9\% (cultivares Supremo e Safira, respectivamente), com variações de 4,4 e 1,0 pontos percentuais entre os lotes de cada cultivar, respectivamente. A análise semiautomatizada, realizada com o auxílio do software Tomato Analyzer, possibilita a identificação de variações estreitas no grau de desenvolvimento embrionário de lotes de sementes de pepino, uma vez que as sementes cuja área embrionária ocupa espaço inferior a 78,1\% da cavidade interna são mais propensas a originarem plântulas menos desenvolvidas.
\end{abstract}

Termos para indexação: Cucumis sativus, controle de qualidade, análise de imagens, raios-x.

\section{Introduction}

One of the possible morphological variations associated with seed performance is the embryonic area, which is relationship between degree of embryo development and space available in the internal seed cavity (Marcos-Filho et al., 2010). The study of this characteristic has been mainly possible as a consequence of improvement in image analysis techniques, specifically for $\mathrm{x}$-rays, allowing for the establishment of relationships with seed physiological potential.

Among the principal information originating from research on this topic is the lower germination of Lithraea molleoides (aroeira-branca) seeds with an embryonic area of less than $100 \%$ of the internal seed cavity area (Machado and Cicero, 2003), abnormal seedlings and ungerminated seeds from partially formed Cecropia pachystachya (embaúba) seeds (Pupim et al., 2008), low germination of castor bean seeds with less than $50 \%$ of the internal cavity area occupied

${ }^{1}$ Submitted on 06/11/2012. Accepted for publication on 10/28/2012.

${ }^{2}$ Departamento de Produção Vegetal, Universidade de São Paulo - ESALQ, Caixa Postal 9, 13418-900 - Piracicaba, SP, Brasil.

*Corresponding author $<$ francisco1@usp.br> 
by the embryo (Carvalho et al., 2010) and decreases in the percentage of normal seedlings from bell pepper seeds with free areas (empty spaces) between the embryo and endosperm greater than 2.7\% (Dell'Aquila, 2007) and with between 50 and $75 \%$ occupation of the internal cavity by the embryo and endosperm (Gagliardi and Marcos-Filho, 2011).

Although the results of those mentioned researches were consistent, they were generally based on visual estimates of embryo and/or endosperm development in the seed internal cavity, with the exception of the study by (Dell'Aquila, 2007). An alternative for eliminating the inconsistency and subjectivity of that evaluation has been proposed by Marcos-Filho et al. (2010), using a semiautomated evaluation of the embryonic area of cotton and cucurbit seeds with a Tomato Analyzer program, developed primarily for evaluating the phenotypic characteristics of tomato fruits (Brewer et al., 2008).

In the commercial production of cucumber seeds, the temporary storage of fruits after harvest is indispensable to obtain maximum germination and vigor, allowing for continued seed maturation, if this was not completed in the field (Barbedo et al., 1994). Recently, it has been observed that cucumber fruits harvested at 30 and 35 days after anthesis had 30 and $75 \%$ of their seeds with a completely filled embryonic cavity (visual analyses of X-ray images), which was directly related to germination, that is, with 38 and $88 \%$ of normal seedlings respectively (Nakada et al., 2011).

In spite of a rigorous quality control program by seed companies and the production of lots with high physiological potential, there are still opportunities for scientific and technological innovation, with the identification of morphological variations in seeds and improvements in lot classification methods. The objective of this research was to evaluate the efficiency of a semi-automated procedure for identifying variations in the degree of embryonic development in commercial cucumber seeds lots and their possible relationship with germination and seedling growth.

\section{Material and Methods}

This research was carried out between November 2009 and July 2010, using seeds of two cucumber cultivars (Supremo and Safira), each represented by four lots. Seed water content was determined by the oven method at $105^{\circ} \mathrm{C}$, during $24 \mathrm{~h}$ (Brasil, 2009). In the preliminar determination of physiological potential, four replicates of 50 seeds per lot were submitted to the germination test using rolls of paper towels, moistened with a water, volume equivalent to 2.5 times the weight of dry paper and maintained in a germinator at $25^{\circ} \mathrm{C}$. Evaluations were performed on the fourth (germination first count) and eighth days after sowing, as established by the Rules for Seed Testing (Brasil, 2009).

For vigor evaluation, apart from the germination first count, the seeds were submitted to the saturated salt accelerated aging (SSAA), using plastic boxes (11 x $11 \times 13 \mathrm{~cm})$ as individual compartments, to which were added $40 \mathrm{~mL}$ of a $\mathrm{NaCl}$ solution (40 $\mathrm{g}$ in $100 \mathrm{~mL}$ of distilled water), to provide $76 \%$ relative humidity, according to (Jianhua and McDonald, 1996). The samples of each lot (6 $\mathrm{g}$ each) were distributed to form a single layer on the surface of a metal mesh suspended within the box. Seed samples were kept in a jacketed water chamber at $41^{\circ} \mathrm{C}$, during 96 hours (Lima and Marcos-Filho, 2009). After aging, a germination test evaluated the mean percentage of normal seedlings four days after sowing. Seeds were also evaluated regarding seedling emergence, with four replications of 50 seeds for each lot, distributed on polystyrene trays with 200 cells per tray containing Plantmax ${ }^{\circledR}$ substrate. After sowing, the trays were kept in a protected environment at $25^{\circ} \mathrm{C}$. The percentage of seedling emergence was measured eight days after sowing.

Evaluation of Seed Embryonic Area: 100 seeds from each lot were X-rayed using a model MX-20 DC-12 digital Faxitron X-ray, connected to a Core 2 Duo computer (3.16 GHz, 2 GB RAM, 160 GB Hard Disk) and a MultiSync LCD1990SX 17" monitor). The x-rays were performed with the seeds positioned $14.3 \mathrm{~cm}$ from the X-ray emission source and using double-faced transparent tape on a retro projector transparency $(29.7 \times 21.0 \times 0.1 \mathrm{~cm})$. The radiographed seeds were then placed in individual cells in a plastic tray (100 cells/ tray) for germination. The embryonic area was determined from the X-rayed seeds using the Tomato Analyzer software (Brewer et al., 2008), according to the procedures described by Marcos-Filho et al. (2010). Three categories of embryonic area were defined based on the mean (M) and standard deviation (sd) of the values obtained for each lot: category I - seeds with an embryonic area lower than the mean minus the standard deviation ( $<\mathrm{M}-\mathrm{sd})$; category II - seeds with an embryonic area in the interval between the mean minus the standard deviation and the mean plus the standard deviation $(\mathrm{M} \pm \mathrm{sd})$; category III - seeds with an embryonic area greater than the mean plus the standard deviation $(>\mathrm{M}+\mathrm{sd})$. The results were expressed as the percentage of area occupied by the embryo in relation to the total area of the seed, limited by the external perimeter of the seed coat.

Seedling Length: evaluated by a computer program of seedling image analysis, Seed Vigor Imaging System ${ }^{\circledR}$ (Hoffmaster et al., 2003), described by Marcos-Filho et al. (2009), providing the individual seedling length originated from each seed submitted to the embryonic area evaluation. Seeds were placed in paper towel rolls ( 25 seeds per roll) to germinate, as 
previously described, with an evaluation 4 days after sowing. Seeds were identified on the germination paper according to the cell numbering of the plastic tray. The seedlings (normal and abnormal) and ungerminated seeds were photographed with a digital camera (model D1 Nikon) connected to a computer (Pentium 4, 3.0 GHz, 1 GB RAM, 160 GB Hard Disk and a 21 " monitor). Results were expressed in centimeters (0.1).

Statistical Procedure: data for germination, accelerated aging, embryonic area (without any category separation) and seedling length were submitted to an analysis of variance, using a completely randomized design, and the means compared by the Tukey test ( $\mathrm{p} \leq 0.05$ ), using the ASSISTAT statistical program (Silva and Azevedo, 2002). Data for the classification of seed embryonic area were statistically analyzed, using only the percentage of seeds within each category of embryonic area, and in the case of the evaluation of seedling length, considering the means and the standard deviations of the data classified in each category. A linear correlation analysis was made between the data of these two variables.

\section{Results and Discussion}

Results for germination and vigor of the Supremo cultivar seeds indicated lower physiological potential for lot 4 (Table 1). 'Safira' seed lots showed high germination and the evaluations of germination first count, saturated salt accelerated aging and seedling emergence confirmed the high vigor of these seeds; no differences were identified between seed lots 5 to 8 (Table 1).

Table 1. Germination (G), germination first count (GFC), saturated salt accelerated aging (SSAA), seedling emergence (SE) and embryonic area (maximum and minimum) values of cucumber seeds, Supremo and Safira cultivars.

\begin{tabular}{|c|c|c|c|c|c|c|c|}
\hline \multirow{2}{*}{ Cultivar } & \multirow{2}{*}{ Seed lots } & \multirow[t]{2}{*}{ G } & GFC & SSAA & \multirow[t]{2}{*}{$\mathrm{SE}$} & \multicolumn{2}{|c|}{ Embryonic area $(\%)$} \\
\hline & & & ------ & & & Min. value & Max. value \\
\hline \multirow{4}{*}{ Supremo } & 1 & $99 a$ & $96 \mathrm{a}$ & $92 \mathrm{a}$ & $97 \mathrm{a}$ & 71.1 & 81.0 \\
\hline & 2 & $99 \mathrm{a}$ & $99 \mathrm{a}$ & $95 \mathrm{a}$ & $97 \mathrm{a}$ & 75.0 & 83.4 \\
\hline & 3 & 99 a & $98 \mathrm{a}$ & $94 \mathrm{a}$ & $97 \mathrm{a}$ & 74.0 & 85.0 \\
\hline & 4 & $90 \mathrm{~b}$ & $89 \mathrm{~b}$ & $66 \mathrm{~b}$ & $93 \mathrm{~b}$ & 65.6 & 87.0 \\
\hline C.V. $(\%)$ & - & 3.1 & 4.0 & 6.2 & 2.8 & - & - \\
\hline \multirow{4}{*}{ Safira } & 5 & $100 \mathrm{a}$ & $97 \mathrm{a}$ & $98 \mathrm{a}$ & $98 \mathrm{a}$ & 76.4 & 85.7 \\
\hline & 6 & $100 \mathrm{a}$ & $97 \mathrm{a}$ & $95 \mathrm{a}$ & $99 \mathrm{a}$ & 76.2 & 85.7 \\
\hline & 7 & $99 \mathrm{a}$ & $95 \mathrm{a}$ & $97 \mathrm{a}$ & $100 \mathrm{a}$ & 74.9 & 84.4 \\
\hline & 8 & $98 \mathrm{a}$ & $93 \mathrm{a}$ & $94 \mathrm{a}$ & $99 \mathrm{a}$ & 69.6 & 86.2 \\
\hline C.V. (\%) & - & 2.4 & 4.5 & 3.4 & 2.5 & - & - \\
\hline
\end{tabular}

In each column, means followed by the same letter do not differ by the Tukey test, $(p \leq 0.05)$.

The highest variations of embryonic area occurred among the seeds of lot 4 (Supremo cultivar). A difference of 21.4 percentage points was observed between the maximum and minimum values for the seeds of this lot, with have been variation around twice higher than values obtained for lots 1, 2 and 3 (Table 1). Similarly, for the Supremo cultivar, the highest difference was observed for lot 8 (16.6 percentage points), whereas lots 5, 6 and 7 showed a mean value of 9.4.

It is worth emphasized that at the time of X-ray analyses, seed water content was between 5.6 and 6.8\% (Supremo cultivar) and 5.1 to $6.5 \%$ (Safira cultivar). These differences (less than 1.5 percentage points) may be considered consistent and reliable for identify seed parts (Gagliardi and MarcosFilho, 2011). Wider variations in seed water content can affect the optical density and difficult the identification of free spaces on the radiography (Liu et al., 1993).

One of the possible causes of the morphological variations identified in this study is the stage of fruit maturation when the seeds were extracted. Plant flowering is not completely uniform, even in cultivars with a determinate growth habit (which isn't the case in cucumber), consequently generating uneven pollination, fertilization and maturation (Marcos-Filho et al., 2010). Recent research has revealed that the percentage of seeds with the maximum degree of embryonic development (full seeds) was associated to the state of fruit maturation, i.e., when seeds were extracted from fruits harvested 30 days after anthesis, only $35 \%$ of the seeds were totally full, whereas when harvested at 35 days after anthesis, the percentage of full seeds had increased to $75 \%$ (Nakada et al., 2011). This indicates that complete occupation of the internal seed cavity may not occur even under rigorous knowledge of stage of fruit maturation for harvest.

In this context, the identification of seeds with small morphological variations, which are difficult to detect visually, could be a concrete step to assure consistent information about the possible relationships with seedling performance. Although a greater variation in embryonic area was observed 
in lot 4 , analysis of the data showed a lower mean percentage of the embryonic area for lot $1(76.8 \%)$, with the highest values being obtained for lots 3 and 4 (Table 2). With regard to the Safira cultivar, lots 5 and 7 were lower $(p \leq 0.05)$ than lot 8 , but the difference between the best and the worst lot was up to one percentage point.

Table 2. Means \pm standard deviation obtained for: percentage of embryonic area (EA) of seeds and percent of seedling length (SL) and linear correlation coefficient (LCC) between embryonic area and seedling length of eight seed lots of cucumber, Supremo and Safira cultivars.

\begin{tabular}{|c|c|c|c|c|}
\hline Cultivar & Seed lot & EA $(\%)$ & SL (cm.seedling ${ }^{-1)}$ & LCC (r) \\
\hline \multirow{4}{*}{ Supremo } & 1 & $76.8 \pm 2.3 \mathrm{c}$ & $8.8 \pm 3.6 b$ & $0.253^{* *}$ \\
\hline & 2 & $79.6 \pm 1.9 \mathrm{~b}$ & $13.5 \pm 3.5 \mathrm{a}$ & $0.091^{\mathrm{ns}}$ \\
\hline & 3 & $81.2 \pm 2.1 \mathrm{a}$ & $14.2 \pm 3.3 \mathrm{a}$ & $0.353^{* *}$ \\
\hline & 4 & $81.1 \pm 2.8 \mathrm{a}$ & $9.5 \pm 4.3 b$ & $0.320 * *$ \\
\hline C.V. $(\%)$ & - & 1.5 & 32.4 & - \\
\hline \multirow{4}{*}{ Safira } & 5 & $80.7 \pm 1.9 b$ & $16.6 \pm 3.4 b$ & $-0.025^{\mathrm{ns}}$ \\
\hline & 6 & $80.9 \pm 1.8 \mathrm{ab}$ & $19.0 \pm 3.0 \mathrm{a}$ & $0.233 *$ \\
\hline & 7 & $80.5 \pm 1.8 b$ & $14.1 \pm 4.3 \mathrm{c}$ & $0.097^{\mathrm{ns}}$ \\
\hline & 8 & $81.5 \pm 2.4 \mathrm{a}$ & $12.9 \pm 6.7 \mathrm{c}$ & $0.371 * *$ \\
\hline C.V. $(\%)$ & - & 1.3 & 29.3 & - \\
\hline
\end{tabular}

Means followed by the same letter in columns do not differ statistically between each other, by the Tukey test $(\mathrm{p} \leq 0.05)$. $(\mathrm{r})$ values: $*=$ significant at $5 \% * *=$ significant at $1 \%$; ${ }^{\text {ns }}=$ non significant

The largest seedling lengths were observed in lots 2 and 3 (Supremo cultivar) and for lot 6 (Safira cultivar). Although seeds of lots 1 and 4 showed differences $(p \leq 0.05)$ regarding the embryonic area, seedling length values were similar; this was also observed in lots 7 and 8 of the Safira cultivar (Table 2). The low linear correlation coefficients between the embryonic area and seedling length (Table 2) indicated that analysis of the internal seed morphology cannot be used to indirectly estimate seedling size four days after germination. Studies on bell pepper seed showed a significant correlation $\left(r^{2}=0.807 *\right)$ between seed area (embryo + endosperm) and primary root length (Dell'Aquila, 2007); however, the effects on the seedling development were not analyzed for primary root lengths greater than $2 \mathrm{~mm}$. Therefore, the correlation between these determinations may be more probable at the start of the germination process (from primary root emission), decreasing proportionally with seedling growth.

The seed classification into categories of embryonic area made possible the association of germination with the degree of embryonic development for some lots, as observed in Figure 1, with lower germination in category $\mathrm{I}(<78.1 \%)$ for lots 3, 4 and 8 compared to categories II and III. The semi-automated evaluation of the embryonic area allowed for identification of small morphological variations among seeds, which is difficult to detect visually (Figure 2). This advantage of computerized analysis allowed the definition of a smaller interval of variation (78.1 to $82.5 \%$ ) compared to that reported in the literature ( 50 to $75 \%$ ) for the same category (Machado and Cicero, 2003; Gagliardi and Marcos-Filho, 2011).

Lot 1 (Supremo cultivar) showed $68 \%$ of the seeds with an embryonic area of less than $78.1 \%$ (category I), different from the other lots, which had a greater percentage of seeds in category II (Figure 1). Even with differences of up to 23 percentage points (lots 7 and 8), all of the Safira cultivar lots showed a higher percentage of seeds with an embryonic area ranging between 78.1 to $82.5 \%$ (category II). These results confirm the existing variability in commercial cucumber seed lots, also observed in bell pepper, with variations between lots of up to $9 \%$ in the number of seeds classified in the same category (50 to $75 \%$ ) of the area occupied by the embryo + endosperm (Gagliardi and Marcos-Filho, 2011).

The classification into categories allowed the identification of seed lots with similar characteristics for the proportion of the internal seed cavity occupied by the embryo. Lots 3 and 4 (Supremo cultivar) were very similar in the percentage of seeds within each category of embryonic area (Figure 1A), without showing, however, the same behavior for germination. In categories II and III, the germination of seed lot 3 was higher than for lot 4 (difference of 7 percentage points), suggesting the action of other factors which may influence physiological potential besides the internal morphology, such as the action of microorganisms or natural seed deterioration without showing visible symptoms in the x-rays (Van der Burg et al., 1994). This type of influence may have occurred in the present study since seeds of the same category, that is, with 
similar embryonic areas and without any apparent damage evident on the $\mathrm{x}$-rays, gave rise to normal and abnormal seedlings (Figure 2). Similar results were obtained for bell pepper by Gagliardi and Marcos-Filho (2011), with abnormal seedlings or ungerminated seeds originating from seeds with a completely filled internal cavity (embryo + endosperm).

\section{Cv. Supremo}
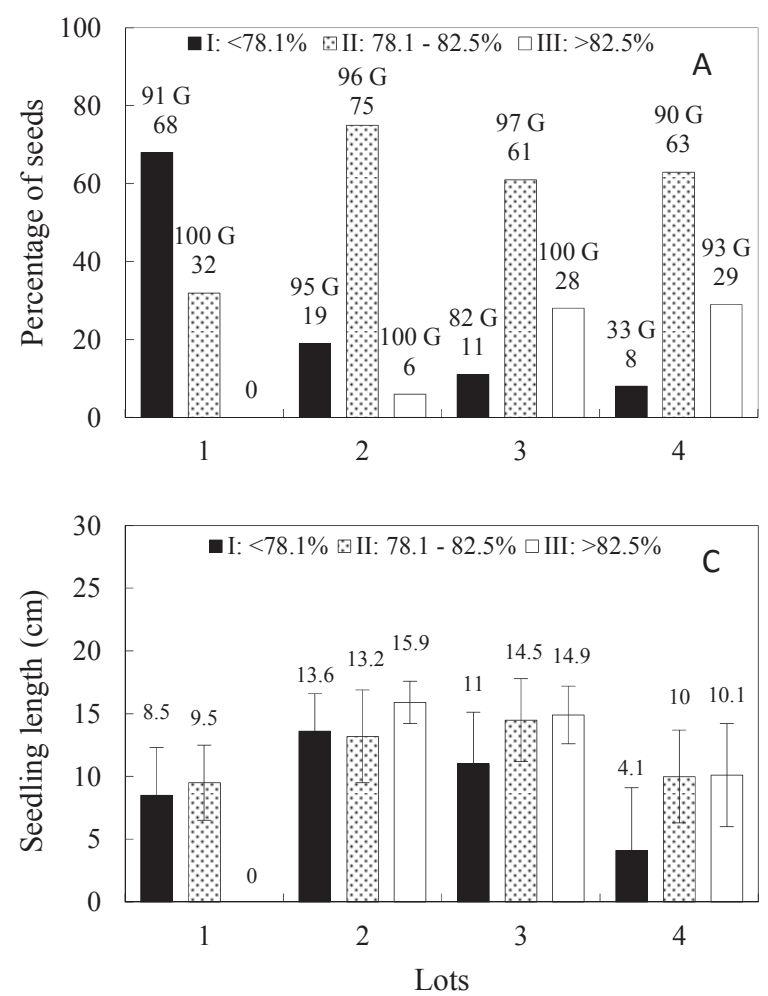

Cv. Safira
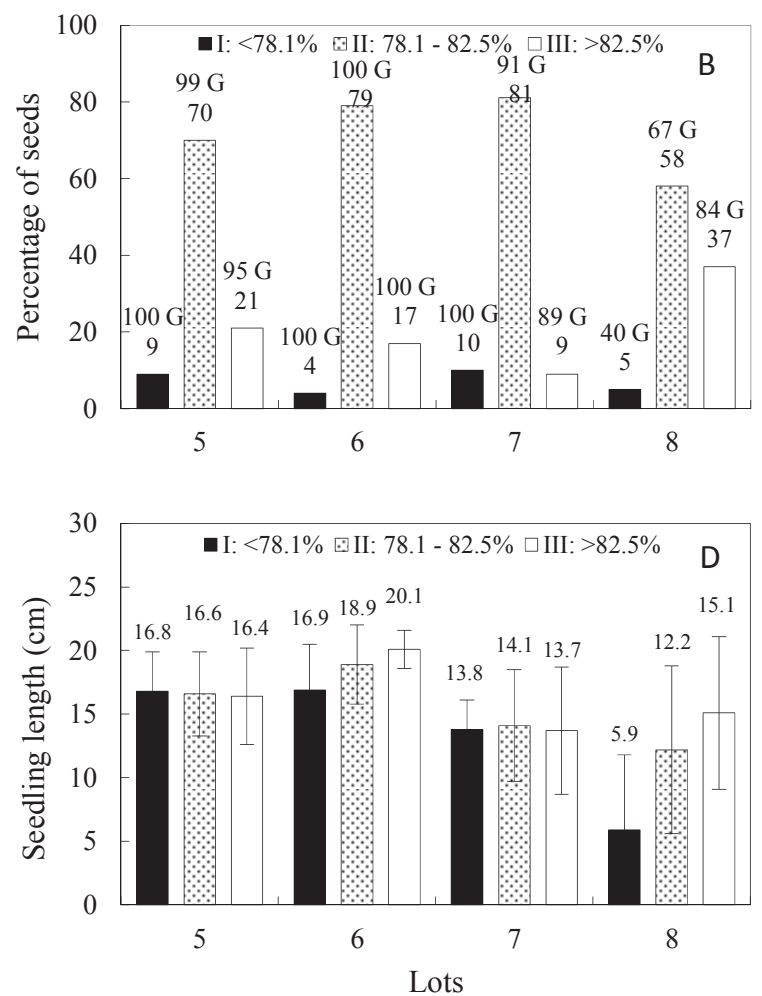

Figure 1. Percentage of seeds, germination and seedling length (mean \pm standard deviation) for each category of embryonic area (I: $<78.1 \%$, II: 78.1 to $82.5 \%$ and III: $>82.5 \%$ ) of four lots of cucumber seeds, Supremo and Safira cultivars.

In contrast, seeds with an embryonic area smaller than $78.1 \%$ had the lowest percentages of germination, mainly in lots 3 and 4 (Supremo cultivar) and 8 (Safira cultivar). This indicates a possible relationship between the degree of development of the embryo and seed performance. Therefore, the high percentage of partial filled seeds in commercial cucumber lots (due to the harvesting of fruits with different degrees of maturation) may result in a reduction in germination, as observed by Nakada et al. (2011), in seeds extracted from fruits harvested at 30 and 35 days after anthesis.

The evaluation of seedling length showed variations between the categories of embryonic area with a distinct difference between seed lots. For most lots, seeds with a larger embryonic area (categories II and III) corresponded to the more developed seedlings, as can be observed for lots 2, 3, 4, 6 and 8 (Figures 1C and 1D). However, this relationship may be directly attributed to the low seed germination of some lots, indicating that decreases in embryonic area appears to affects more directly the germination than the development (size) of normal seedlings
(Figures 1A and 1D). It was observed that when there was no wide variation in the germination between the embryonic area categories of the same lot, seedling length was similar (lot 5, for example, germination between 95 and 100\% and seedling length from 16.4 to $16.8 \mathrm{~cm}$ ). However, for lot 6 , which showed no germination differences, there was a tendency for increased seedling growth with an increase in embryonic area.

The use of automation for determining this relationship (embryonic area/area available in the internal seed cavity) has been an important advance in seed technology research, mainly because it reduced possible interpretive errors due to evaluations based on visual estimates. The semi-automated determination of the embryonic area of cucumber seeds using the Tomato Analyzer software even permitted the identification of small differences in embryonic area among seeds of the same lot. The inclusion of this procedure by the seed industry may improve the seed classification process, consequently resulting in the commercialization of more uniform lots. The process of identifying differences in seed physiological 
potential associated with morphological variations, as a result of a probable consumption of reserves during storage, is a further procedure which may help professionals working in seed quality control programs.
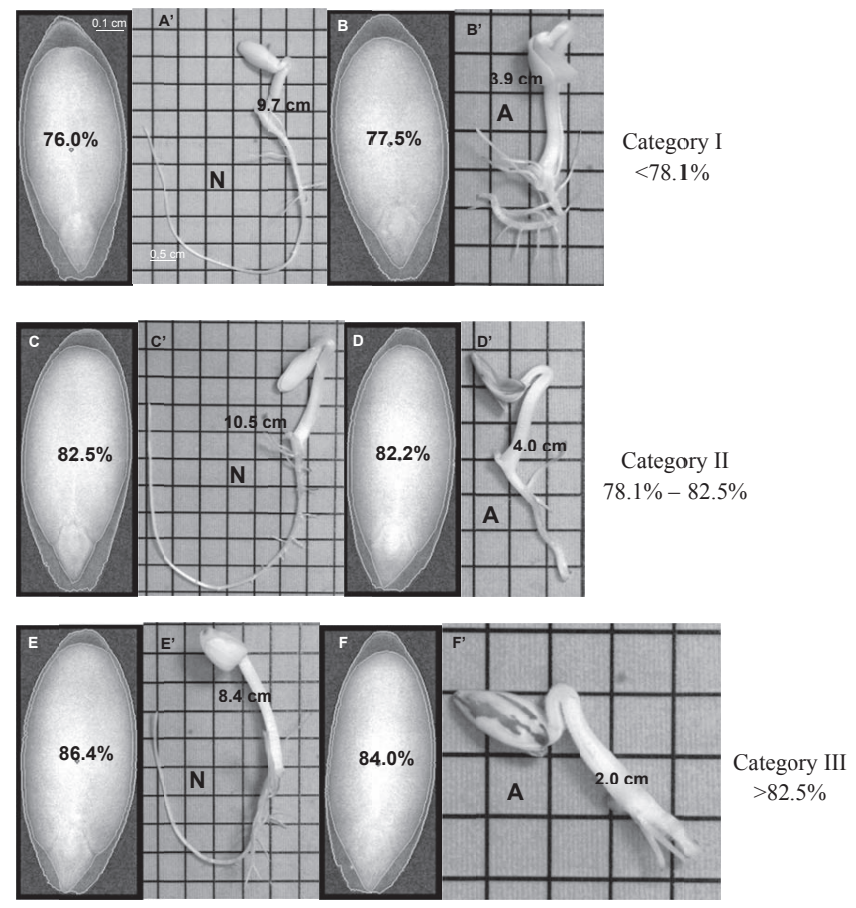

Figure 2. Images obtained by x-rays of cucumber seeds ( $\operatorname{lot} 4)$, cv. Supremo, with representatives of each category of embryonic area and their respective seedlings (normal $=\mathrm{N}$ or abnormal $=\mathrm{A}$ ), assessed four days after starting the germination test.

\section{Conclusion}

Semiautomated analysis allows identification of small variations in degree of embryonic development of the cucumber seeds originating from different seed lots; cucumber seed lots that contain a high percentage of seeds with embryonic areas less than $78.1 \%$ are more likely to produce less developed seedlings.

\section{Acknowledgements}

To "Fundação de Amparo à Pesquisa do Estado de São Paulo" and CNPq for financial support to this research.

\section{References}

BARBEDO, C.J.; NAKAGAWA, J.; BARBEDO, A.S.C.; ZANIN, A.C.W. Influência da idade e do período de repouso pós-colheita de frutos de pepino cv. Rubi na qualidade fisiológica de sementes. Horticultura Brasileira, v.12, n.2, p.118-124. 1994.

BRASIL. Ministério da Agricultura, Pecuária e Abastecimento. Regras para análise de sementes. Ministério da Agricultura, Pecuária e Abastecimento. Secretaria de Defesa Agropecuária. Brasília: MAPA/ACS, 2009. 395p http://www.agricultura.gov.br/arq_editor/file/laborat $\%$ c3\%b3rio/sementes/ regras $\% 20$ para $\% 20$ analise $\% 20 \mathrm{de} \% 20$ sementes.pdf

BREWER, M.T.; RODRIGUEZ, G.; GONZALO, M.J.; LANG, L.; SULLIVAN, D.; DUJMOVIC, N.; FUJIMURA, K.; GRAY, S.; KNAAP, E. Tomato Analyzer (TA) user manual version 2.2.00. 18p. 2008. http://www. oardc.ohio-state.edu/vander knaap. Accessed on: Oct. $20^{\text {th }} 2008$.

CARVALHO, M.L.M.; ALVES, R.A.; OLIVEIRA, L.M. Radiographic analysis in castor bean seeds (Ricinus communis L.). Revista Brasileira de Sementes, v.32, n.1, p.170-175, 2010. http://www.scielo.br/scielo.php?script=sci arttext\&pid=s0101-31222010000100019\&lng=pt\&nrm=iso\&tlng=en

DELL'AQUILA, A. Pepper seed germination assessed by combined $\mathrm{X}$-radiography and computer-aided imaging analysis. Biologia Plantarum, v.51, n.4, p.777-781, 2007. http://wwwueb.asuch.cas.cz/bp/contents_bp51-4.htm

GAGLIARDI, B.; MARCOS-FILHO, J. Relationship between germination and bell pepper seed structure assessed by the X-ray test. Scientia Agricola, v.68, n.4, p.411-416, 2011. http://www.scielo.br/scielo.php?script=sci arttext\&pid=S0103-90162011000400004\&lng=pt\&nrm=iso\&tlng=en

HOFFMASTER, A.L.; FUJIMURA, K.; McDONALD, M.B.; BENNETT, M.A. An automated system for vigour testing three-day-old soybean seedlings. Seed Science and Technology, v.31, n.3, p.701-713, 2003. http://www. ingentaconnect.com/content/ista/sst/2003/00000031/00000003/art00019

JIANHUA, Z.; McDONALD, M.B. The saturated salt accelerated aging test for small-seeded crops. Seed Science and Technology, v.25, n.1, p.123-131, 1996.

LIMA, L.B.; MARCOS-FILHO, J. Condicionamento fisiológico de sementes de pepino e relação com desempenho das plantas em campo. Revista Brasileira de Sementes, v.31, n.3, p.27-37, 2009. http://www.scielo.br/scielo.php?script=sci arttext\&pid=s0101-31222009000300003\&lng=pt\&nrm=iso\&tlng=pt

LIU, Y.; VAN DER BURG, W.J.; AARTSE, J.W.; VAN ZWOL, R.A.; JALINK, H.; BINO, R.J. X-ray studies on changes in embryo and endosperm morphology during priming and imbibition of tomato seeds. Seed Science Research, v.3, n.3, p.171-178, 1993. http://journals.cambridge.org/action/displayabstract?frompage $=$ online \&aid $=1353132 \&$ fullexttype $=$ ra\& fileid $=$ s0960258500001756

MACHADO, C.F.; CICERO, S.M. 'Aroeira branca' seed quality evaluation by the X-ray test. Scientia Agricola, v.60, n.2, p.393-397, 2003. http://www scielo.br/scielo.php?script=sci_arttext\&pid=S0103-90162003000200026\&lng $=\mathrm{pt} \& \mathrm{nrm}=\mathrm{iso} \& \operatorname{lng}=\mathrm{en}$

MARCOS-FILHO, J.; GOMES-JUNIOR, F.G.; BENNETT, M.A.; WELLS, A.A.; STIEVE, S. Using tomato analyzer software to determine embryo size in X-rayed seeds. Revista Brasileira de Sementes, v.32, n.2, p.146153, 2010. http://www.scielo.br/scielo.php?script=sci arttext\&pid=s0101$31222010000200018 \& \operatorname{lng}=$ pt\&nrm=iso\&tlng=en

MARCOS-FILHO, J.; KIKUTI, A.L.P.; LIMA, L.B. Métodos para avaliação do vigor de sementes de soja, incluindo a análise computadorizada de imagens. Revista Brasileira de Sementes, v.31, n.1, p.102-112, 2009. http://www.scielo. br/scielo.php?script=sci_arttext\&pid $=$ S0101-31222009000100012\&lng=pt $\& n r m=$ iso $\&$ tlng $=$ pt

NAKADA, P.G.; OLIVEIRA, J.A.; MELO, L.C.; GOMES, L.A.A.; VON PINHO, E.V.R. Desempenho fisiológico e bioquímico de sementes de 
pepino nos diferentes estádios de maturação. Revista Brasileira de Sementes, v.33, n.1, p.113-122, 2011. http://www.scielo.br/scielo.php?script=sci_ arttext\&pid=s0101-31222011000100013\&lng=pt\&nrm=iso\&tlng=pt

PUPIM, T.L.; NOVEMBRE, A.D.L.C.; CARVALHO, M.L.M.; CICERO, S.M. Adequação do teste de raios X para avaliação da qualidade de sementes de Embaúba (Cecropia pachystachya Trec.). Revista Brasileira de Sementes, v.30, n.2, p.28-32, 2008. http://www.scielo.br/scielo.php?script=sci arttext\&pid=s0101-31222008000200004\&lng=pt\&nrm=iso\&tlng=pt
SILVA, F.A.S.; AZEVEDO, C.A.V. Versão do programa computacional Assistat para o sistema operacional Windows. Revista Brasileira de Produtos Agroindustriais, v.4, n.1, p.71-78, 2002. http://www.deag.ufcg.edu.br/rbpa/ rev41/art410.pdf

VAN DER BURG, W.J.; AARTSE, J.W.; VAN ZWOL, R.A.; JALINK, H.; BINO, F.J. Predicting tomato seedling morphology by X-ray analysis of seeds. Journal of the American Society for Horticultural Science, v.119, p.258-263, 1994. http://journal.ashspublications.org/content/119/2/258.abstract 